\title{
EHMTI-0093. Investigation of 5-HT2B receptor pathways with relevance to a mouse migraine model
}

\author{
M Kremser ${ }^{*}$, A Hunfeld, H Lübbert \\ From 4th European Headache and Migraine Trust International Congress: EHMTIC 2014 \\ Copenhagen, Denmark. 18-21 September 2014
}

\section{Introduction}

Recent research raises the question whether the serotonin $2 \mathrm{~B}$ receptor (5-HT2B) plays a role in the pathogenesis of migraine. Clinical studies revealed that the $5-\mathrm{HT} 2 \mathrm{~B} / 2 \mathrm{C}$ agonist meta-Chlorophenylpiperazine (mCPP) induces migraine-like headache more likely in migraineurs than in subjects without a history of migraine. We therefore developed an animal model for chronic migraine, where we are able to induce a neurogenic inflammation in the dura mater of hypoxic mice with 5-HT2B agonists. This inflammation can be blocked by specific 5 -HT2B inhibitors.

Until now little is known about the 5-HT2B receptor: It is expressed on endothelial cells of blood vessels, but it may also be present on other cell types. Like most of the other serotonin receptors it is a G protein-coupled receptor, but the native signal transduction pathway after receptor activation is not clear yet.

\footnotetext{
Aims

Investigation of the 5-HT2B receptor in a primary cell culture system to determine native signal transduction pathways.
}

\section{Methods}

Cultivation of primary cells. Validation of the presence of the receptor. Signal transduction assays.

\section{Results}

Stimulation with the 5-HT2B/2C agonist mCPP induced concentration-dependent ERK phosphorylation in 5-HT2B positive primary cells.

Department of Animal Physiology, Faculty of Biology and Biotechnology, Bochum, Germany

\section{SpringerOpen $^{\odot}$}

(C) 2014 Kremser et al; licensee Springer. This is an Open Access article distributed under the terms of the Creative Commons Attribution License (http://creativecommons.org/licenses/by/2.0), which permits unrestricted use, distribution, and reproduction in any medium, provided the original work is properly cited.

\section{Conclusions}

Activation of the 5-HT2B receptors may stimulate cell proliferation and angiogenesis and therefore alter the vascular system of the dura mater, which may result in a higher susceptibility for migraine.

No conflict of interest.

Published: 18 September 2014

doi:10.1186/1129-2377-15-S1-F13

Cite this article as: Kremser et al.: EHMTI-0093. Investigation of 5-HT2B receptor pathways with relevance to a mouse migraine model. The Journal of Headache and Pain 2014 15(Suppl 1):F13.

Submit your manuscript to a SpringerOpen ${ }^{\mathcal{O}}$ journal and benefit from:

- Convenient online submission

- Rigorous peer review

- Immediate publication on acceptance

- Open access: articles freely available online

- High visibility within the field

- Retaining the copyright to your article

Submit your next manuscript at $\boldsymbol{s p r i n g e r o p e n . c o m ~}$ 